\title{
ARTIFICIAL NEURAL NETWORKS APPLIED FOR SOIL CLASS PREDICTION IN MOUNTAINOUS LANDSCAPE OF THE SERRA DO MAR ${ }^{(1)}$
}

\author{
Braz Calderano Filho( ${ }^{(2)}$, Helena Polivanov ${ }^{(3)}$, César da Silva Chagas ${ }^{(2)}$, Waldir de \\ Carvalho Júnior ${ }^{(2)}$, Emílio Velloso Barroso ${ }^{(3)}$, Antônio José Teixeira Guerra ${ }^{(4)}$ \& \\ Sebastião Barreiros Calderano(2)
}

\begin{abstract}
SUMMARY
Soil information is needed for managing the agricultural environment. The aim of this study was to apply artificial neural networks (ANNs) for the prediction of soil classes using orbital remote sensing products, terrain attributes derived from a digital elevation model and local geology information as data sources. This approach to digital soil mapping was evaluated in an area with a high degree of lithologic diversity in the Serra do Mar. The neural network simulator used in this study was JavaNNS and the backpropagation learning algorithm. For soil class prediction, different combinations of the selected discriminant variables were tested: elevation, declivity, aspect, curvature, curvature plan, curvature profile, topographic index, solar radiation, LS topographic factor, local geology information, and clay mineral indices, iron oxides and the normalized difference vegetation index (NDVI) derived from an image of a Landsat-7 Enhanced Thematic Mapper Plus (ETM+) sensor. With the tested sets, best results were obtained when all discriminant variables were associated with geological information (overall accuracy 93.2 - 95.6 \%, Kappa index 0.924 - 0.951, for set 13). Excluding the variable profile curvature (set 12), overall accuracy ranged from 93.9 to $95.4 \%$ and the Kappa index from 0.932 to 0.948 . The maps based on the neural network classifier were consistent and similar to conventional soil maps drawn for the study area, although with more spatial details. The results show the potential of ANNs for soil class prediction in mountainous areas with lithological diversity.
\end{abstract}

Index terms: artificial neural networks, terrain attributes, digital mapping.

(1) Part of the first author's Doctoral Thesis presented at the Geology Post-Graduation Program of the Federal University of Rio de Janeiro - IGEO/UFRJ. Received for publication on October 2, 2013 and approved on July 25, 2014.

(2) Researcher, Embrapa Solos. Rua Jardim Botânico, 1024. CEP 22460-000 Rio de Janeiro (RJ), Brazil. E-mail: bccalder@gmail.com.br, cesar.chagas@embrapa.br, waldir.carvalho@embrapa.br, sbastian@gmail.com.br

(3) Professor, Geology Department, Universidade Federal Rio de Janeiro - UFRJ. Av. Athos da Silveira Ramos, 274, bloco G. Cidade Universitária. CEP 21941-916. Rio de Janeiro (RJ). E-mail: hpolivanov@gmail.com.br, emilio@geologia.ufrj.br

(4) Professor, Geography Department, UFRJ. E-mail: antoniotguerra@gmail.com.br 


\title{
RESUMO: REDES NEURAIS ARTIFICIAIS APLICADAS NA PREDIÇÃO DE CLASSES DE SOLOS EMÁREAS DE PAISAGENS MONTANHOSAS DA SERRA DO MAR
}

\begin{abstract}
A informação de solo é necessária para o gerenciamento do ambiente agrícola. O objetivo deste trabalho foi aplicar redes neurais artificiais (RNAs) para a predição de classes de solos, utilizando como fonte de dados produtos de sensores remotos orbitais, atributos do terreno derivados de um modelo digital de elevação e informação da geologia local, visando avaliar a utilização dessa abordagem no mapeamento digital de solos, em área com elevado grau de diversidade litológica na Serra do Mar. O simulador de redes neurais utilizado foi o JavaNNS e o algoritmo de aprendizado, o backpropagation. Para a predição das classes de solos, testaram-se diferentes combinações entre as variáveis discriminantes selecionadas: elevação, declividade, aspecto, curvatura, plano de curvatura, perfil de curvatura, indice topográfico, radiação solar, fator topográfico LS, informações da geologia local e índices minerais de argila, óxidos de ferro e vegetação por diferença normalizada (NDVI), derivados de uma imagem do sensor ETM+ do LANDSAT 7. Dos conjuntos testados, os melhores resultados foram obtidos com todas as variáveis discriminantes associadas às informações de geologia, alcançando exatidão global entre 93,2 e 95,6\% e indice Kappa entre 0,924 e 0,951 (conjunto 13). Excluindo a variável perfil de curvatura (conjunto 12), a exatidão global alcançada oscilou entre 93,9 9 95,4\% e Kappa entre 0,932 e 0,948. Os mapas inferidos pelo classificador por redes neurais evidenciaram coerência e semelhança com o mapa de solos convencional, produzido para área de estudo, apresentando porém, mais detalhes espaciais. Os resultados apresentaram o potencial de utilização de RNAs na predição de classes de solos de áreas montanhosas com diversidade litológica.
\end{abstract}

Termos de indexação: redes neurais artificiais, atributos do terreno, mapeamento digital.

\section{INTRODUCTION}

The environmental impacts related to production activities have generated an increased demand for updated and detailed soil information, stimulating the need for evolution and adaptation of conventional methods for acquiring this information. Especially regarding execution time, conventional methods fail to provide quantitative information that meet the requirements of environmental modeling and support environmental planning in a timely manner.

The technological innovations of the last two decades enabled access to a set of tools related to computational intelligence, remote sensing data, computer products and conventional cartography, enabling progress in the forms of acquisition and analysis of environmental information. Benefiting from these innovations, the methods for generating soil information were adjusted and improved by incorporating digital mathematical techniques for spatial soil prediction.

These techniques currently used in soil science are more widely known as digital soil mapping "DSM" (McBratney et al., 2003). Several techniques are used for DSM, e.g., the application of parametric methods such as logistic regression, geostatistical analysis and fuzzy logic, as well as non-parametric approaches such as auto-learning algorithms (ALA), decision trees, neural networks, and expert systems (Zhou et al., 2004; Grinand et al., 2008; Sarmento et al., 2008), based on the quantitative analysis of spatially distributed characteristics of soil formation factors (Florinsky, 2012).

Artificial neural network is an artificial intelligence technique based on the biological concept of the functioning of neurons with the ability to acquire, store, and use experiential knowledge and belong to the same family as expert systems and knowledge-based learning approaches (Key et al., 1989).

The application of artificial neural networks in soil studies has been widely used to estimate soil properties and attributes (Minasny et al., 2004), specifically for the prediction and distribution of soil types, as in the studies of Zhu (2000), Carvalho Júnior (2005), Chagas (2006), and Sirtoli (2008).

The aim of this study was to apply artificial neural networks to predict soil types by using orbital remote sensing products, terrain attributes derived from a digital elevation model and local geology information as data source. Thus, the possibility of using this approach for soil type prediction was evaluated specifically for the mountainous landscapes of the Serra do Mar (Brazil), with a high degree of lithological diversity.

\section{MATERIAL AND METHODS}

The study area is located in the mountainous region of the State of Rio de Janeiro and occupies 
approximately 48,469 ha, covering parts of the territorial districts of Cordeiro, Trajano de Morais, Duas Barras, Bom Jardim, Casimiro de Abreu, and of Nova Friburgo (Figure 1). The climate is humid mesothermal tropical, temperatures are evenly distributed throughout the year and there is little or no water deficit. Summers are mild, with an average annual temperature of $17.8{ }^{\circ} \mathrm{C}$ and minimum of $13{ }^{\circ} \mathrm{C}$ in winter. The natural vegetation is represented by sub-perennial rainforest in the high parts and wetland sub-perennial rainforest in the lower parts.

The study area is part of the geomorphological unit of "Hill Reverse fault and Coastal Range on the Serra dos Órgãos Plateau", with a complex terrain with large variations in altitude. According to Matos et al. (1980), DRM (1982) and Mendes et al. (2007), in this area, Neoproterozoic geological units are predominant, consisting mostly of orthogneiss and migmatites of the Rio Negro Complex and granodioritic orthogneiss of the Serra dos Órgãos Batholith. They are interspersed with gneiss bands derived from the Paraíba do Sul Group (leuco-gneiss and metasedimentary rocks) and igneous rocks of granodioritic to granitic composition, more rarely gabbroic, which intruded these units. To a lesser extent, unconsolidated alluvial deposits of sandyclayey, silty-clayey and sandy consistency occur.

Initially, geological and soil maps were drawn at a scale of 1:50,000 to perform this study, based on the conventional soil survey method described by Embrapa (1995). The geological map was obtained from scanning the topographic sheets of Cordeiro, Quartéis, Duas Barras and Trajano de Morais (Matos et al., 1980; DRM, 1982). It was used as environmental predictor variable in digital mapping, providing information about soil source material (Figure 2). The conventional soil map drawn by Calderano Filho (2012), allowed defining the dominant soil types within the area, which were used as output variables in predictive models, besides serving as a reference to evaluate the results by digital classification with ANNs (Figure 3). For the conventional soil map, 40 complete soil profiles, 30 extra profiles (A and B horizons) and 456 points of field observation were used. The soil types used as output variables are presented in table 1.

For digital mapping, 13 predictor variables were used: elevation, declivity, aspect, curvature, curvature plan, curvature profile, topographic wetness index (TWI), solar radiation, and LS factor derived from a digital elevation model (DEM) with a $30-\mathrm{m}$ spatial resolution, which, together with the geological map of the area, were associated with the indices of clay minerals, iron oxide, and the normalized difference vegetation index (NDVI), derived from an image of the ETM + Landsat 7 sensor from August 1999. In addition to 40 profiles and 30 extra soil samples, in a total of 300 horizons analyzed, 256 of the 456 field observation points were selected for use. The choice of the variables for digital soil type discrimination was based on soil formation factors, according to the Jenny (1941) equation. These variables reflect the major factors that affect pedogenetic processes and with greater possibility of correlation for the prediction of local soil classes.

The DEM was obtained from interpolation of $20-\mathrm{m}$ equidistant contour lines, hydrography and elevation

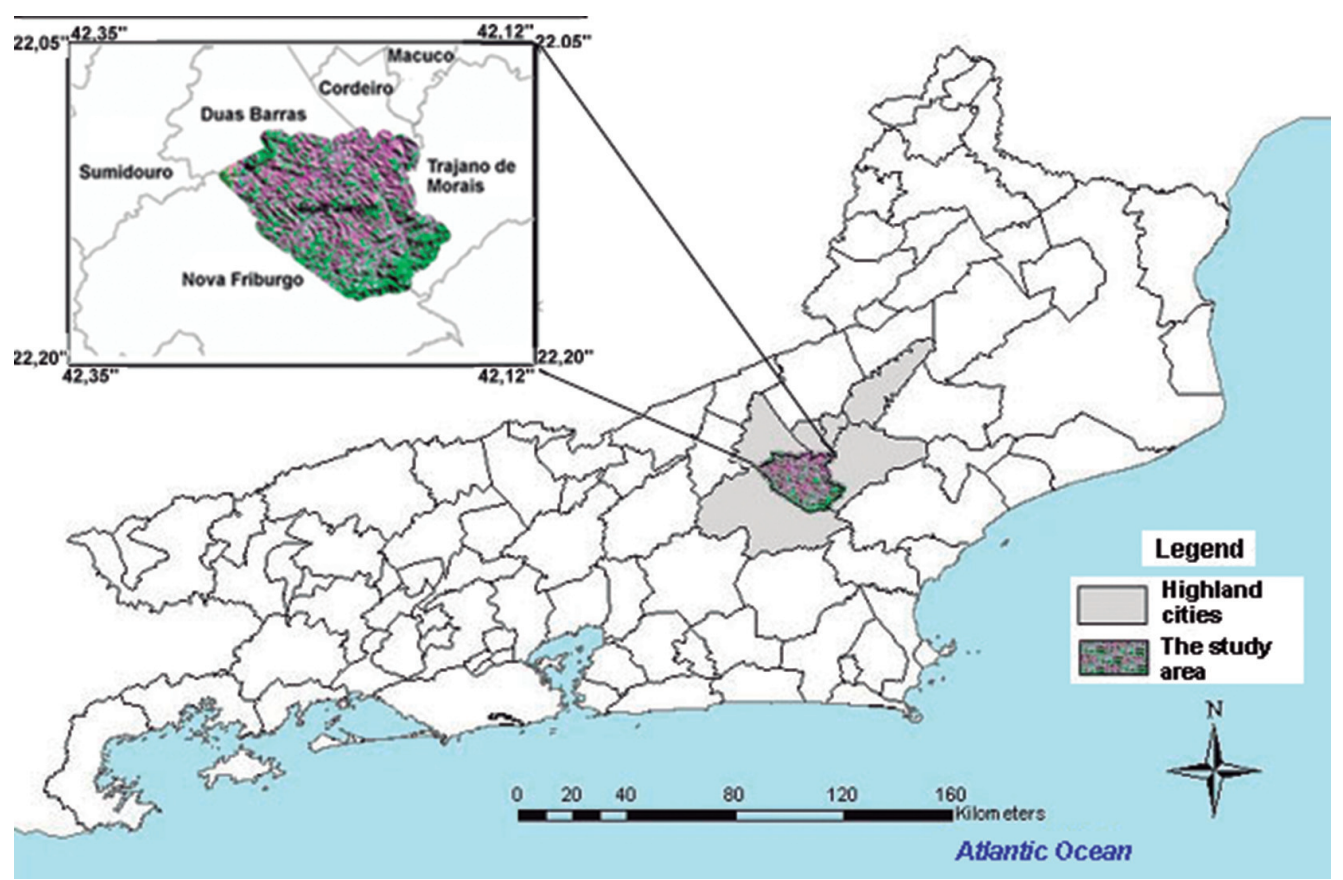

Figure 1. Study area in the highlands of Rio de Janeiro State. 
points derived from the IBGE topographic maps, on the 1:50,000 scale, referring to the topographic sheets of Quartéis, Cordeiro, Trajano de Morais, Duas Barras and Casimiro de Abreu, using the "top to raster" tool of ArcGIS 9.2 software (ESRI, 2004). From the DEM free of spurious pits, the terrain attributes elevation, declivity, aspect, curvature, curvature plan, curvature

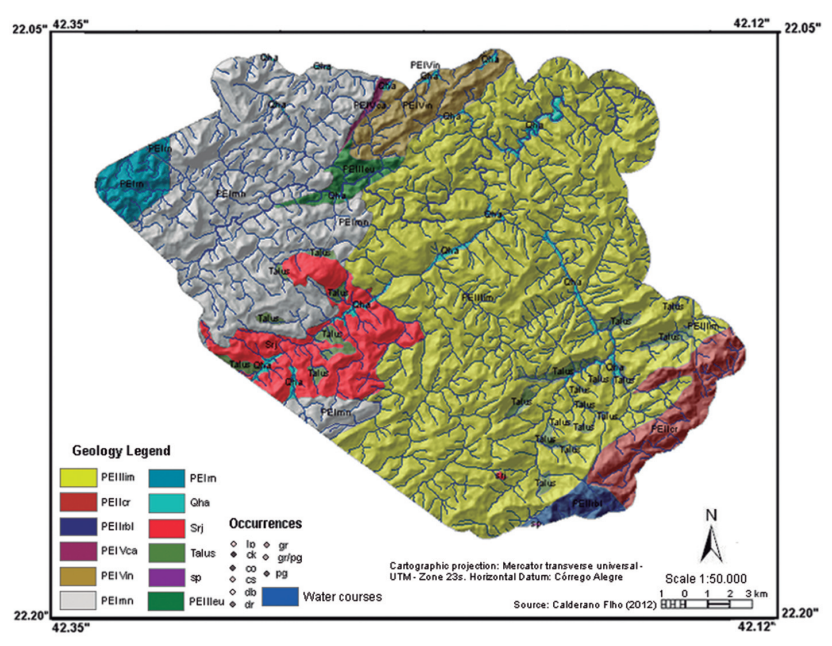

Figure 2. Lithological units within the area.

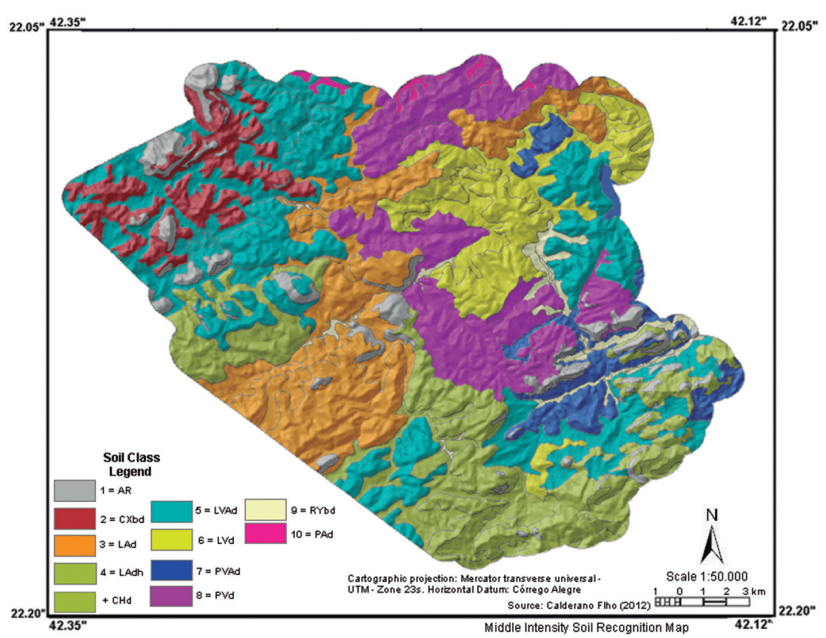

Figure 3. Soil conventional map of the area. profile, topographic wetness index (TWI), solar radiation, and LS factor (slope length and declivity) were derived.

Moore (1993) defined the TWI index as a function of declivity and the contributing area per orthogonal width unit towards flow direction, calculated by equation 1 :

$$
\mathrm{TWI}=\ln \left(\frac{A s}{\tan \beta}\right)
$$

where $A_{s}$ is the contributing area [(cumulative flow + 1) $\times$ grid cell size in $\mathrm{m}^{2}$ ] and $\beta$ the declivity expressed in radians.

The factor LS was obtained using an adaptation routine developed by Engel (2003), according to equation 2.

$$
\begin{gathered}
\text { LS }=\text { Pow }\{([\text { flowacc }] \times 40 / 22.13), 0.4\} \times \\
\text { Pow }\{(\operatorname{Sin}([\text { slopedg }] \times 3.14 / 180) / 0.0896), 1.3)\}
\end{gathered}
$$

where Pow $=$ Power Function; flowacc $=$ cumulative flow grid; $\operatorname{Sin}=$ sine function; and slopedg = declivity, in degrees.

Solar radiation was obtained based on equations of Fu \& Rich (2000), using the Solar Analyst extension of ArcGis 9.2, which computes overall solar radiation for each DEM pixel within the study area, based on the calculation of potential insolation. The other terrain attributes were obtained directly from ArcGIS 9.2 (ESRI, 2004), using the Spatial Analyst option.

The Landsat 7 image, originally with a spatial resolution of $28.5-\mathrm{m}$, was resampled by the nearest neighbor method for a 30-m spatial resolution; then, it was used to derive the clay mineral indices by dividing band 5 ( 1.55 to $1.75 \mu \mathrm{m}$ ) by band 7 (2.08 to $2.35 \mu \mathrm{m})$; iron oxide by dividing band 3 (0.63 to $0.69 \mu \mathrm{m})$ by band $1(0.45$ to $0.52 \mu \mathrm{m})$; and NDVI as the ratio between the weighted difference of total measured near-infrared and red reflectance (band 4 - band 3/band $4+$ band 3) through ERDAS Imagine software (version 8.5).

The neural network simulator "Java Neural Network Simulator" version 1.1 (JavaNNS, 2001) was

Table 1. Soil classes used as output variables in classification by artificial neural networks

\begin{tabular}{ccl}
\hline Class & Output order & \\
\hline 1 & $1^{\text {st }}$ & Rnit \\
2 & $2^{\text {nd }}$ & Dystrophic Haplic Cambisols or leptic - CXbd (Inceptisols) \\
3 & $3^{\text {rd }}$ & Dystrophic Yellow Latosols A moderate type - LAd (Oxisols) \\
4 & $4^{\text {th }}$ & Dystrophic Humic Yellow Latosols - Ladh (Oxisols) associated to Dystrophic Humic Cambisols (Inceptisols) \\
5 & $5^{\text {th }}$ & Dystrophic Red-Yellow Latosols A moderate type - LVAd (Oxisols) \\
6 & $6^{\text {th }}$ & Dystrophic Red Latosols Typical - LVd (Oxisols) \\
7 & $7^{\text {th }}$ & Dystrophic Red-Yellow Argisols - PVAd (Ultisols) \\
8 & $8^{\text {th }}$ & Dystrophic Red Argisols - PVd (Ultisols) \\
9 & $9^{\text {th }}$ & Dystrophic Fluvic Neosols (Entisols) associated to Dystrophic Fluvic Cambisols - RYbd (Inceptisols) \\
10 & $10^{\text {th }}$ & Dystrophic Yellow Argisols - Pad (Ultisols) \\
\hline
\end{tabular}


used and the learning algorithm was the backpropagation. In order to facilitate the training process and avoid network saturation, values related to discriminating variables used as inputs in the neural network (terrain attributes, indices derived from Landsat 7 image and geology grid), were rescaled to the interval between 0 and 1, using ArcGIS 9.2 for terrain and geology attributes, and ERDAS Imagine 8.5 for indices derived from the Landsat 7 image. Then, using the "layer stack" module in ERDAS Imagine 8.5, images were assembled by combining all environmental variables used in the study, which served to collect the samples fed to the neural network simulator.

Twelve different training sets were assembled, combining land attributes, indices derived from Landsat 7 image, and geological information, with a minimum of six and maximum of 13 discriminant variables in each set, by varying predictor variables within the input layer, as shown in table 2 . Ten classes of dominant soil were standardized as output variable for each set, as shown in table 1 . For each soil type, 300 training samples and 250 samples were used to validate ANNs, totaling 3,000 and 2,500 samples, respectively. The samples obtained independently (stratified samples) were collected from images containing the discriminant variables, with ERDAS Imagine 8.5 software, and distributed within the study area in order to best represent each soil type characteristics. The files obtained were converted to JavaNNS format. For each set tested, one training file and one validation file were created. Zhu (2000) suggested that the set sizes be 30 times the number of soil types to be mapped, and $50 \%$ of this value for validation samples. Differing from Zhu (2000), we used $84 \%$ of the number of training samples for validation. To organize the training files and present results, the sets were separated into three groups: (T12 and T13), (Tps) and (T9G, T9G1 and TB9_2), as shown in table 2.

In the definition of network architectures, single and double-layer networks were standardized for training, with 1 to 55 neurons each, two training sequences each with 10,000 cycles, considered as training time $1(\mathrm{t})$. The 10 best networks of each set with Kappa values above 0.85 received a new training cycle (from 20,000 to 30,000 cycles), considered here as training time 2 (TP).

Thus, various network architectures were tested by varying the number of neurons in the input layer, corresponding to the number of discriminant environmental variables used (Table 2), varying the neuron number in the inner layer(s) and the inner layer number; and, all of them with 10 neurons in the output layer corresponding to soil types observed in conventional mapping (Table 1).

The ANN training phase, using supervised learning, consisted of the random distribution of interneuron weights from -0.5 to 0.5 , with a variable learning rate $(\eta)$ of 0.2 for the initial 10,000 cycles; of 0.1 for cycles from 10,000 to 20,000 ; and 0.075 for the

Table 2. Arranged training and validation sets and inserted variables

\begin{tabular}{|c|c|c|c|c|c|c|c|c|c|c|c|c|c|}
\hline \multirow{3}{*}{ Variable } & \multicolumn{13}{|c|}{ Training and validation sets of the ANNs (T) } \\
\hline & \multicolumn{2}{|c|}{ Block 3} & \multirow[b]{2}{*}{$\mathbf{T p}$} & \multicolumn{4}{|c|}{ Block 2} & \multirow[b]{2}{*}{ Tp5 } & \multirow[b]{2}{*}{ Tp6 } & \multirow[b]{2}{*}{ T9G } & \multicolumn{2}{|c|}{ Block 1} & \\
\hline & T13 & T12 & & Tp1 & Tp2 & Tp3 & Tp4 & & & & T9G1 & TB9_2 & \\
\hline Elevation & ok & ok & ok & ok & ok & ok & ok & ok & ok & ok & ok & ok & \\
\hline Declivity & ok & ok & ok & ok & ok & ok & ok & ok & ok & ok & ok & ok & \\
\hline Aspect & ok & ok & ok & ok & ok & ok & - & - & - & - & - & - & \\
\hline Curvature & ok & ok & - & - & - & - & - & - & - & - & - & - & \\
\hline Curv. plan & ok & ok & ok & ok & ok & ok & ok & ok & ok & ok & ok & ok & \\
\hline Curv. profile & ok & - & - & - & - & - & - & - & - & - & - & - & \\
\hline TWI index & ok & ok & ok & ok & ok & ok & ok & ok & ok & ok & $\mathrm{ok}$ & $\mathrm{ok}$ & \\
\hline Solar radiation & ok & ok & ok & ok & ok & - & - & - & ok & - & ok & - & \\
\hline LS factor & ok & ok & ok & ok & - & - & - & - & ok & ok & - & ok & \\
\hline Iron oxide & ok & ok & ok & ok & ok & ok & ok & ok & ok & ok & ok & ok & \\
\hline Clay mineral & ok & ok & ok & ok & ok & ok & ok & ok & ok & ok & ok & ok & \\
\hline NDVI & ok & ok & ok & - & - & - & - & - & ok & ok & ok & ok & \\
\hline Geology & ok & ok & ok & ok & ok & ok & ok & - & ok & ok & ok & - & \\
\hline Predictor var. & 13 & 12 & 11 & 10 & 9 & 8 & 7 & 6 & 10 & 9 & 9 & 8 & \\
\hline Set & $\mathrm{T} 13$ & $\mathrm{~T} 12$ & $\mathrm{Tp}$ & $\mathrm{Tp} 1$ & $\mathrm{Tp} 2$ & Tp3 & $\operatorname{Tp} 4$ & Tp5 & Tp6 & T9G & T9G1 & TB9_2 & \\
\hline \multirow[t]{2}{*}{ Trained NNs } & R13 & $\mathrm{R} 12$ & $\mathrm{RP}$ & Rp1 & Rp2 & Rp3 & $\mathrm{Rp} 4$ & Rp5 & Rp6 & $\mathrm{R} 9 \mathrm{G}$ & R9G1 & R9_2 & $\mathrm{Rs}_{\mathrm{s}}$ \\
\hline & $\mathrm{R} 13 \mathrm{~d}$ & $\mathrm{R} 12 \mathrm{~d}$ & $\mathrm{RPd}$ & RP1d & RP2d & RP3d & RP4d & RP5d & RP6d & R9Gd & R9G1d & R9_2d & Rdp \\
\hline
\end{tabular}

T, Tp, TG and TB: arranged training sets (simplified numbering to differentiate ANN results); ok: contain; - do not contain; R: artificial network architecture; Rs: single-layer network; and Rd: double-layer network. 
final cycles from 20,000 to 30,000. The increment method was used to add neurons to the inner layers, observing the mean squared error behavior during training. This process was repeated until the network reached a low training error (Zhu, 2000).

At the end of the training process, the networks were subjected to validation for the choice of that or those suited for soil type discrimination in the study area. Results were evaluated for their accuracy or reliability level and overall accuracy of classification (Kappa index) of the ANNs, derived from a confusion matrix (Congalton \& Green, 1999), using validation samples. A significance matrix of Kappa among the considered networks was also generated to evaluate results obtained from ANNs selected for each set, and assist in the final choice of the best network(s) architecture(s) for data classification. At the end of the process, the four network architectures with best results for the Kappa index, among all evaluated sets, were selected for soil type prediction.

The final results obtained with $\mathrm{ANNs}$ and classified scene images were generated using the "Funcpow" application developed by Vieira (2000), and manipulated by software ERDAS Imagine 8.5 and ArcGIS 9.2. The soil type maps produced by the selected neural networks were then compared to the conventional soil map, considering it as reference and evaluating the concordance of the information.

\section{RESULTS AND DISCUSSION}

The best results of ANN classification throughout the training process with the tested and assessed combinations were obtained with set 13 , using all discriminant variables, resulting in an overall accuracy of 93.2 to $95.6 \%$ and Kappa index from 0.924 to 0.951 (Tables 5 and 7). Excluding the variable profile curvature, set 12 , the overall accuracy ranged from 93.9 to $95.4 \%$ and the Kappa index from 0.932 to 0.948 (Table 4). In these two sets, the majority of trained networks with single and double-layer, had an excellent classifier performance, with Kappa values greater than 0.75 , according to the reference values suggested by Landis \& Koch (1977) and Monserud \& Leemans (1992).

The final choice and selection of the best ANN architecture for soil type prediction was based on the Kappa index and overall accuracy results, which were obtained with validation samples through confusion matrix (Tables 3 and 6) and by analyzing the Kappa significance matrix among the selected networks (Tables 4 and 7). It was observed that the Kappa index varied depending on the neuron number within the inner layer and discriminant variables.

Partly corroborating Foody \& Arora (1997), who claimed that larger and more complex networks are more efficient in characterizing a training set properly. The increasing complexity of networks with additional inner layer neurons, the use of two internal layers, and more training cycles contributed to enhance the classification accuracy. Similarly, geology information used as input variable improved the final classification accuracy, as confirmed in tests and validations, comparing networks with a double inner layer of block 1, with and without the geological information. For example, among the compared networks, there was a $26 \%$ increase from Rd88_9G to Rd88_9d; $25.3 \%$ from Rd11_9G to Rd11_9d; and 42.88 \% from Rd22_9G to Rd22_9d. Results for all trained and validated network architectures were provided by Calderano Filho (2012). Thus, geology information as discriminant variable was critical to demonstrate significant differences in the final classification, when used in combination with other predictor variables. The influence of lithology on soil distribution in the landscape was confirmed in studies of McKenzie \& Ryan (1999), McKenzie \& Austin (1993) and Thomas et al. (1999).

Double-layer had a slightly better performance than single-layer networks in all tests and validations. For set 12 in the double-layer networks, from the $12^{\text {th }}$ neuron onwards, the overall accuracy was above $81 \%$ and from the $16^{\text {th }}$ neuron on, above $84 \%$ for all trained networks. From this set, the best results in training time 2 were obtained with R4444_TP12d networks with an overall accuracy of $94.6 \%$ and Kappa index of 0.940 , and R4848_TP12d with overall accuracy of $95.4 \%$ and Kappa index of 0.948 (Table 3). The networks showed excellent classification results for all output classes, with balanced performance among pre-established output classes. Tables 3 show the Kappa index and overall accuracy results obtained by the confusion matrix of the best ANN architectures of set 12 .

The classification results (Table 3) of both networks were high, classifying all pre-established output classes with good performance among the classes. In network R4444_TP12d, the largest percentage of hits (100\%) refers to classes 2 and 10, wherein Haplic Cambisols (Inceptisols) and Yellow Argisols (Ultisols) are found. The worst performance was observed for Class 6, with a Dystrophic Red Latosols (Oxisols), with an accuracy of $76.8 \%$. From the total pixels considered in class 6,42 were assigned to class 2,12 to class 5 , and 4 to class 7 (Table 3 ). The highest percentage of incorrectly allocated pixels was $23 \%$ in class 6 , followed by class 3 with $8 \%$, class 8 with $7 \%$ and class 4 with $6 \%$. The misallocations were $4 \%$ in class 9 and below $2 \%$ in the others, except for classes 2 and 10.

In network R4848_TP12d, the largest percentage of hits (100\%) is related to class 10, Yellow Argisols (Ultisols). The classification performance was worst in Class 4, containing Humic Dystrophic Yellow Latosols (Oxisols), with an accuracy of $88.8 \%$ (Table 
3). Following the previous trend, in this network, excluding class 10 , incorrect allocations occurred in class 4 with $11 \%$, class 6 with $10 \%$, class 8 with $7 \%$ and in classes 3 and 9 with $6 \%$, while in the others misallocations were below $2 \%$.

From confusion matrix results and statistical values of $A N N$ validation and due to its performance, set 12 was one of those selected for local soil prediction. Thus, a Kappa significance matrix was calculated between the networks to verify the significance of differences among results and choose the best network architecture for final data classification (Table 4). This table shows that the networks containing 48,44 and 55 neurons in the inner layers have higher values of overall accuracy and Kappa index. However, networks with 48 and 44 neurons in the inner layers are superior and were chosen for the final soil type discrimination.

Set 13 , combining all terrain attributes with geology and the three indices derived from the
LANDSAT 7 sensor image, performed best in several trained networks with excellent results in the output classes (Table 6). In this set, the highest overall accuracy, Kappa index, and therefore the best results were obtained with the architectures of $43,45,47,54$ and 55 neurons in the inner layers and training time 2 (Tables 5 and 6 ).

Table 6 presents validation results of the networks R4343_TP13d and R4545_TP13d. The highest percentage of hits (100\%) refers to classes 5 and 10 , in landscapes with Red-Yellow Latosols (Oxisols) and Yellow Argisols (Ultisols) (Table 6). On the other hand, the worst classification performance was observed for class 8, Red Argisols (Ultisols), with an accuracy of $85.6 \%$. In this soil class, major confusion occurred, in which from 250 pixels considered as being of class 8, 18 were allocated to classes 3 and 10 .

In table 6 , the greatest percentage of hits (100\%) refers to classes 2 and 10, containing landscapes with Haplic Cambisols (Inceptisols) and Yellow Argisols

Table 3. Confusion matrix obtained through classification of networks [R4444_TP12d] and [R4848_TP12d] of set 12

\begin{tabular}{|c|c|c|c|c|c|c|c|c|c|c|c|c|c|}
\hline \multicolumn{14}{|c|}{ [R4444_TP12d] } \\
\hline Class & 1 & 2 & 3 & 4 & 5 & 6 & 7 & 8 & 9 & 10 & Total & User & $\mathrm{Z}$ \\
\hline 1 & 243 & 0 & 0 & 4 & 0 & 0 & 0 & 0 & 0 & 0 & 247 & 98.4 & 110.231 \\
\hline 2 & 0 & 250 & 19 & 10 & 0 & 42 & 0 & 0 & 0 & 0 & 321 & 77.9 & 30.209 \\
\hline 3 & 0 & 0 & 231 & 0 & 0 & 0 & 0 & 18 & 0 & 0 & 249 & 92.8 & 50.822 \\
\hline 4 & 7 & 0 & 0 & 234 & 0 & 0 & 0 & 0 & 0 & 0 & 241 & 97.1 & 80.751 \\
\hline 5 & 0 & 0 & 0 & 0 & 249 & 12 & 0 & 0 & 0 & 0 & 261 & 95.4 & 66.213 \\
\hline 6 & 0 & 0 & 0 & 0 & 0 & 192 & 0 & 0 & 0 & 0 & 192 & 100.0 & 0.000 \\
\hline 7 & 0 & 0 & 0 & 2 & 0 & 4 & 245 & 0 & 0 & 0 & 251 & 97.6 & 91.097 \\
\hline 8 & 0 & 0 & 0 & 0 & 0 & 0 & 0 & 232 & 0 & 0 & 232 & 100.0 & 0.000 \\
\hline 9 & 0 & 0 & 0 & 0 & 1 & 0 & 5 & 0 & 240 & 0 & 246 & 97.6 & 89.255 \\
\hline 10 & 0 & 0 & 0 & 0 & 0 & 0 & 0 & 0 & 10 & 250 & 260 & 96.2 & 72.544 \\
\hline $\mathrm{U}$ & 0 & 0 & 0 & 0 & 0 & 0 & 0 & 0 & 0 & 0 & 0 & 0.0 & \\
\hline Total & 250 & 250 & 250 & 250 & 250 & 250 & 250 & 250 & 250 & 250 & 2500 & & \\
\hline Produced & 97.2 & 100.0 & 92.4 & 93.6 & 99.6 & 76.8 & 98.0 & 92.8 & 96.0 & 100.0 & & & \\
\hline \multicolumn{14}{|c|}{ Overall accuracy $=94.6 ;$ Kappa $=0.940 ;$ Variance $=0.000025 ; \mathrm{Z}$ calc. $=188.036 ; \mathrm{Z}$ tab. $=1.96$} \\
\hline \multicolumn{14}{|c|}{ [R4848_TP12d] } \\
\hline 1 & 245 & 0 & 0 & 7 & 0 & 0 & 0 & 0 & 0 & 0 & 252 & 97.2 & 84.505 \\
\hline 2 & 0 & 247 & 0 & 19 & 0 & 3 & 0 & 0 & 0 & 0 & 269 & 91.8 & 49.430 \\
\hline 3 & 5 & 0 & 234 & 0 & 0 & 0 & 0 & 18 & 0 & 0 & 252 & 92.9 & 51.463 \\
\hline 4 & 0 & 0 & 0 & 222 & 0 & 0 & 0 & 0 & 0 & 0 & 227 & 97.8 & 90.318 \\
\hline 5 & 0 & 0 & 0 & 2 & 249 & 17 & 0 & 0 & 1 & 0 & 269 & 92.6 & 52.059 \\
\hline 6 & 0 & 3 & 0 & 0 & 0 & 226 & 0 & 0 & 0 & 0 & 229 & 98.7 & 118.185 \\
\hline 7 & 0 & 0 & 12 & 0 & 0 & 4 & 245 & 0 & 13 & 0 & 274 & 89.4 & 43.262 \\
\hline 8 & 0 & 0 & 0 & 0 & 1 & 0 & 0 & 232 & 0 & 0 & 233 & 99.6 & 209.238 \\
\hline 9 & 0 & 0 & 4 & 0 & 0 & 0 & 5 & 0 & 234 & 0 & 243 & 96.3 & 71.503 \\
\hline 10 & 0 & 0 & 0 & 0 & 0 & 0 & 0 & 0 & 2 & 250 & 252 & 99.2 & 159.727 \\
\hline $\mathrm{U}$ & 0 & 0 & 0 & 0 & 0 & 0 & 0 & 0 & 0 & 0 & 0 & 0.0 & \\
\hline Total & 250 & 250 & 250 & 250 & 250 & 250 & 250 & 250 & 250 & 250 & 2500 & & \\
\hline Produced & 98.0 & 98.8 & 93.6 & 88.8 & 99.6 & 90.4 & 98.0 & 92.8 & 93.6 & 100.0 & & & \\
\hline
\end{tabular}


(Ultisols); however, the worst performance in classification was obtained for class 8 again (Red Argisols - Ultisols), with an accuracy of $83.6 \%$. Form the total pixels considered as being of class 8,12 were assigned to class 5 and 23 to class 10 (Table 6).

The lower performance for the classes of Red Argisols (Ultisols) and Red Latosols (Oxisols) coincides with the difficulty of separating them in the field, where they occur in very similar positions of the landscape. Although the classifier performance and the proportion of correctly allocated pixels was high according to the reference values of Landis \& Koch (1977), the neural networks had greater difficulty in distinguishing these classes. This is explained by the small differences between the covariates curvature plan and profile. The exclusion of the variable curvature profile in the input layer of network R4848_TP12d, from set 12, increased the proportion of correctly allocated pixels in these two classes, reaching an accuracy of $92.8 \%$ in Argisols (Ultisols) and $90.4 \%$ in Red Latosols (Oxisols) (Table 3).

From the results of confusion matrices and other statistical values from the ANN validation (Tables 5 and 6), and according to its performance, set 13 was also chosen to assist the discrimination of soils in the area. Thus, a Kappa significance matrix was generated among the networks to verify the existence of differences, significant or not, among the results and to choose the best network architecture for the final data classification (Table 7).
As shown in table 7, the highest values of overall accuracy and Kappa index were obtained by the double inner layer architectures, and the best performances with the networks R4343_TP13d (207.525) and R4545_TP13d (176.320), which appear to be different from all the others and were also selected to discriminate soil types. At the end of the validation process, the networks [R4444TP_12d], [R4848TP_12d], [R4343_TP13d], and [R4545_TP13d] were defined to generalize the information of the entire study area and discriminate soil types. Classification resulting from ANN application, selected from the sets 12 and 13 with their respective digital soil maps, are shown in figures 4 and 5 and the simplified pedological map in figure 3.

The conventional soil map, produced specifically to serve as reference in the visual assessment of neural network predicted maps, is a map of medium intensity recognition at a scale of 1:50,000, and its legend is found in Calderano Filho (2012). The purpose was not to compare soil map generation methods, mainly because they cannot be contrasted. However, the ANN efficiency in discriminating and spacing soil types over an area with a high degree of biogeophysical complexity (soils, lithology, climate, topography, and vegetation cover) was tested, using easily available and cheap products. Within this framework, areas of difficult access, such as the Amazon region for example, could obtain this information at medium scales, i.e. between 1:50,000 and 1:250,000.

Table 4. Kappa significance matrix and respective indices for the different neural network architectures selected from set 12 TP12d

\begin{tabular}{lrrrrr}
\hline Network & R4343TP & R4444TP & R4646TP & R4848TP & R5555TP \\
\hline Overall accuracy (\%) & 93.9 & 94.6 & 94.0 & 95.4 & 0.948 \\
Kappa & 0.932 & 0.940 & 0.933 & 0.220 & \\
Variance $^{(1)}$ & 0.280 & 0.250 & 0.280 & \\
R4343TP & 176.131 & & & \\
R4444TP & 1.099 & 188.000 & & \\
R4646TP & 0.134 & 0.962 & 176.320 & 202.114 \\
R4848TP & 2.263 & 1.167 & 2.121 & 1.443 \\
R5555TP & 0.816 & 0.280 & 0.680 & & 183.957 \\
\hline
\end{tabular}

(1) Values multiplied by $10^{3}$.

Table 5. Evolution of overall accuracy and Kappa index within double inner layer networks from set 13

\begin{tabular}{lccccc}
\hline Network & Overall accuracy & Kappa & Network & Overall accuracy & Kappa \\
\hline & $\%$ & & & $\%$ & 95.6 \\
R4343_13d(1) & 90.2 & 0.892 & R4343_TP13d ${ }^{(2)}$ & 94.0 & 0.951 \\
R4545_13d & 90.1 & 0.890 & R4545_TP13d & 93.2 & 0.933 \\
R4747_13d & 90.6 & 0.896 & R4747_TP13d & 93.7 & 0.924 \\
R5454_13d & 90.1 & 0.890 & R5454_TP13d & 93.4 & 0.930 \\
R5555_13d & 90.2 & 0.891 & R5555_TP13d & & \\
\hline
\end{tabular}

(1) d: double-layer. ${ }^{(2)}$ TP: training time 2. 
By analyzing figures 3,4 and 5, considering that in the conventional map most mapping units are composed by soil associations, it was stated that the neural network classifier always allocated one of the component members of the mapping unit correctly.
Even by the traditional method, it was difficult to establish components and boundaries between the polygons (soil patches), especially for areas with Red and Red-Yellow Argisols (Ultisols), which occur in similar landscape positions. Similarly, this behavior

Table 6. Confusion matrix obtained through classification of [R4343_TP13d, R4545_TP13d] networks from set 13

\begin{tabular}{|c|c|c|c|c|c|c|c|c|c|c|c|c|c|}
\hline \multicolumn{14}{|c|}{ [R4343_TP13d] } \\
\hline Class & 1 & 2 & 3 & 4 & 5 & 6 & 7 & 8 & 9 & 10 & Total & User & $\mathrm{Z}$ \\
\hline 1 & 240 & 0 & 0 & 7 & 0 & 0 & 0 & 0 & 0 & 0 & 247 & 97.2 & 82.799 \\
\hline 2 & 2 & 240 & 0 & 1 & 0 & 10 & 0 & 0 & 0 & 0 & 253 & 94.9 & 61.476 \\
\hline 3 & 0 & 0 & 246 & 0 & 0 & 5 & 0 & 18 & 0 & 0 & 269 & 91.4 & 48.242 \\
\hline 4 & 8 & 10 & 0 & 242 & 0 & 0 & 0 & 0 & 0 & 0 & 260 & 93.1 & 53.175 \\
\hline 5 & 0 & 0 & 0 & 0 & 250 & 0 & 0 & 0 & 8 & 0 & 258 & 96.9 & 80.798 \\
\hline 6 & 0 & 0 & 0 & 0 & 0 & 222 & 0 & 0 & 0 & 0 & 222 & 100.0 & 0.000 \\
\hline 7 & 0 & 0 & 0 & 0 & 0 & 13 & 245 & 0 & 0 & 0 & 258 & 95.0 & 62.732 \\
\hline 8 & 0 & 0 & 0 & 0 & 0 & 0 & 0 & 214 & 0 & 0 & 214 & 100.0 & 0.000 \\
\hline 9 & 0 & 0 & 4 & 0 & 0 & 0 & 5 & 0 & 240 & 0 & 249 & 96.4 & 73.311 \\
\hline 10 & 0 & 0 & 0 & 0 & 0 & 0 & 0 & 18 & 2 & 250 & 270 & 92.6 & 52.262 \\
\hline $\mathrm{U}$ & 0 & 0 & 0 & 0 & 0 & 0 & 0 & 0 & 0 & 0 & 0 & 0.0 & \\
\hline Total & 250 & 250 & 250 & 250 & 250 & 250 & 250 & 250 & 250 & 250 & 2500 & & \\
\hline Produced & 96.0 & 96.0 & 98.4 & 96.8 & 100.0 & 88.8 & 98.0 & 85.6 & 96.0 & 100.0 & & & \\
\hline \multicolumn{14}{|c|}{ Overall accuracy $=95.6 ;$ Kappa $=0.951 ;$ Variance $=0.000021 ; \mathrm{Z}$ cal. $=207.761 ; \mathrm{Z}$ tab. $=1.96$} \\
\hline \multicolumn{14}{|c|}{ [R4545_TP13d] } \\
\hline 1 & 242 & 0 & 0 & 5 & 0 & 0 & 0 & 0 & 0 & 0 & 247 & 98.0 & 98.386 \\
\hline 2 & 0 & 250 & 0 & 9 & 1 & 27 & 0 & 0 & 0 & 0 & 287 & 87.1 & 39.600 \\
\hline 3 & 0 & 0 & 220 & 0 & 0 & 0 & 0 & 6 & 0 & 0 & 226 & 97.3 & 81.887 \\
\hline 4 & 8 & 0 & 0 & 234 & 0 & 0 & 0 & 0 & 0 & 0 & 242 & 96.7 & 75.668 \\
\hline 5 & 0 & 0 & 0 & 0 & 247 & 0 & 0 & 12 & 0 & 0 & 259 & 95.4 & 65.691 \\
\hline 6 & 0 & 0 & 0 & 0 & 2 & 214 & 0 & 0 & 0 & 0 & 216 & 99.1 & 136.797 \\
\hline 7 & 0 & 0 & 11 & 0 & 0 & 5 & 245 & 0 & 0 & 0 & 261 & 93.9 & 56.868 \\
\hline 8 & 0 & 0 & 0 & 2 & 0 & 0 & 0 & 209 & 0 & 0 & 211 & 99.1 & 133.612 \\
\hline 9 & 0 & 0 & 19 & 0 & 0 & 0 & 5 & 0 & 239 & 0 & 263 & 90.9 & 46.011 \\
\hline 10 & 0 & 0 & 0 & 0 & 0 & 4 & 0 & 23 & 11 & 250 & 288 & 86.8 & 39.142 \\
\hline $\mathrm{U}$ & 0 & 0 & 0 & 0 & 0 & 0 & 0 & 0 & 0 & 0 & 0 & 0.0 & \\
\hline Total & 250 & 250 & 250 & 250 & 250 & 250 & 250 & 250 & 250 & 250 & 2500 & & \\
\hline Produced & 96.8 & 100.0 & 88.0 & 93.6 & 98.8 & 85.6 & 98.0 & 83.6 & 95.6 & 100.0 & & & \\
\hline Overall acc & curacy & $=94.0$ & Kappa & 0.933; & ariance & $=0.000$ & $8 ; \mathrm{Z} \mathrm{ce}$ & $=176$ & 37; Z t &.$=1.96$ & & & \\
\hline
\end{tabular}

Table 7. Kappa significance matrix and respective indices for the different neural network architectures selected from set $13 \_$TPd

\begin{tabular}{lccccc}
\hline Network & R4343TPd & R4545TPd & R4747TPd & R5454TPd & R5555TPd \\
\hline Overall accuracy & 95.6 & 94.0 & 93.2 & 93.7 & 9.930 \\
Kappa & 0.951 & 0.933 & 0.924 & 0.31 & \\
Variance $^{(1)}$ & 0.21 & 0.28 & & \\
R4343TPd & 207.525 & & & \\
R4545TPd & 2.571 & 176.320 & 165.955 & 172.697 \\
R4747TPd & 3.744 & 1.172 & 0.775 & 0.39 \\
R5454TPd & 2.970 & 0.397 & 0.384 & 0.391 \\
R5555TPd & 3.361 & 0.788 & & \\
\hline
\end{tabular}

(1) Values multiplied by $10^{3}$. 

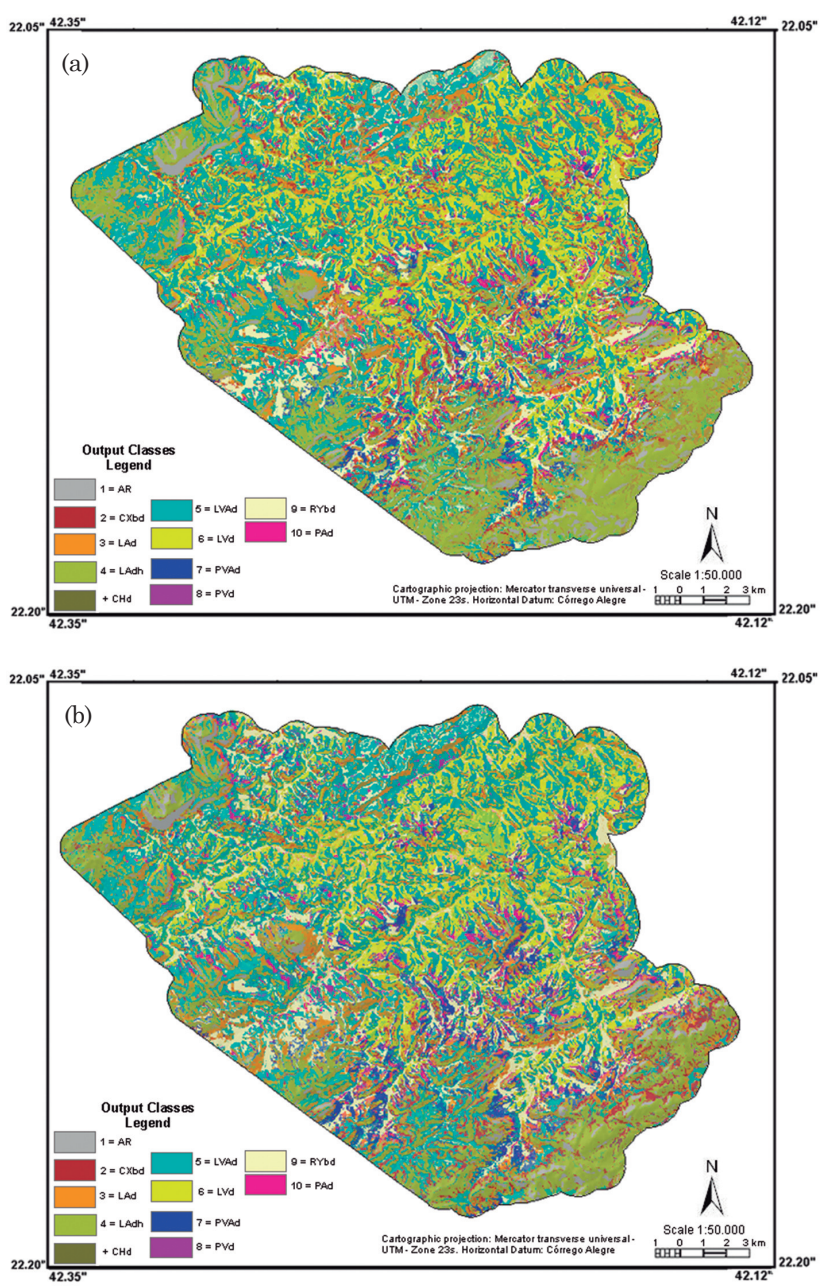

Figure 4. Resulting prediction from application of architectures of networks [R4444TP_12d] (a) and [R4848TP_12d] (b) in the training area.

was found for Humic Dystrophic Yellow Latosols (Oxisols) and Humic Cambisols (Inceptisols), which also occur in very similar landscape positions.

In terms of the visual aspect of classifications, a good design along with a classification consistent with digital maps were observed for the selected networks in all output classes. Litholic Neosols (Entisols) associated with rocky outcrops (RO), Haplic Cambisols (CXbd) (Inceptisols) and Humic Dystrophic Yellow Latosols (LAdh) (Oxisols) follow the lines of the conventional map in a consistent and very similar form in all four classifications. The inconsistency is higher and neural classifier performance is lower when smooth and rough areas are compared in the landscape, as reported in previous studies (Zhu, 2000).

In this type of visual assessment, a clear separation of boundaries among output classes in the resulting maps was also observed, consistent with the conventional map for practically all four networks, except for the classes Fluvic Neosols (Entisols) and Red Argisols (Ultisols), and for some networks tending
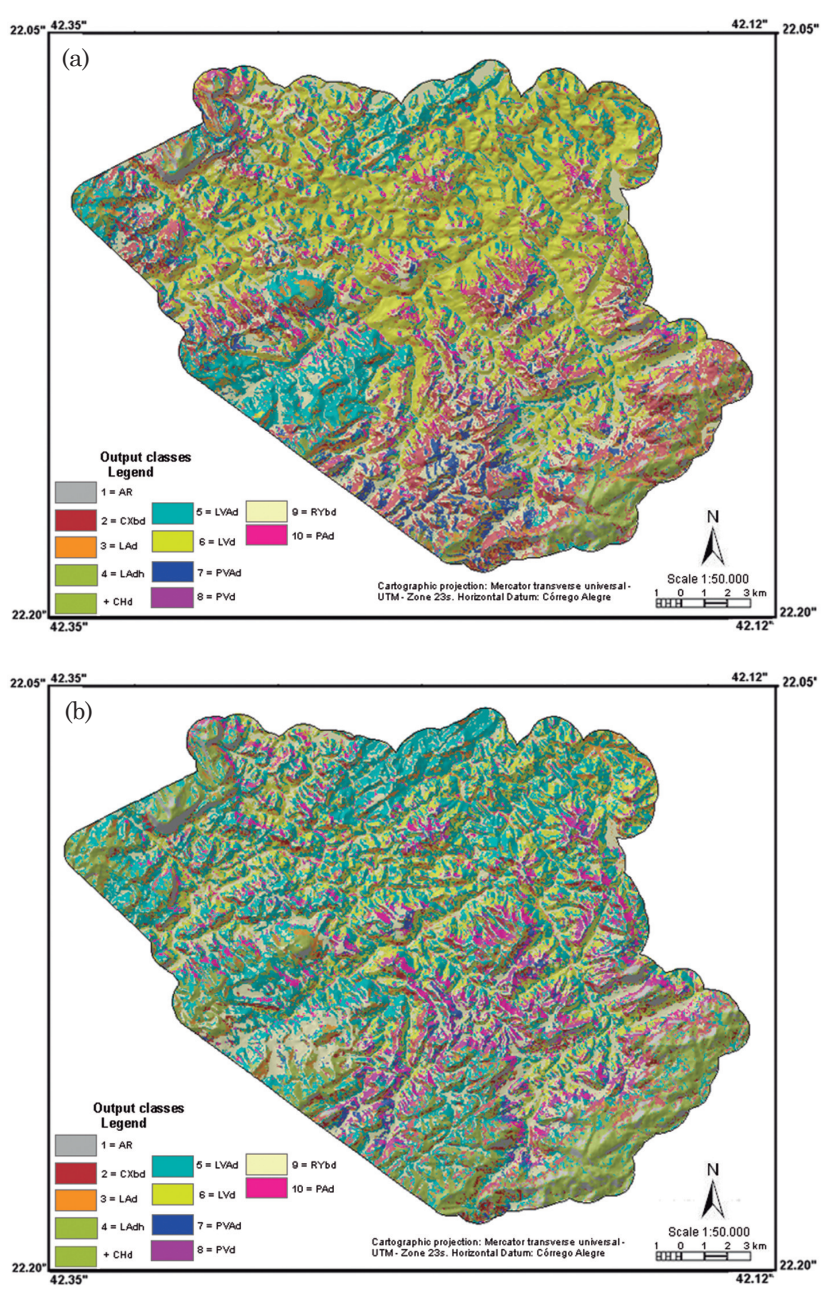

Figure 5. Resulting prediction from application of architectures of networks [R4343TP_13d] (a) and [R4545TP_13d] (b) in the training area.

to overestimate or underestimate data. Even though classifier performance and ratio of correctly allocated pixels were high, as seen in Fluvic Neosols (Entisols), the distribution of this class in the predicted map was overestimated, differing from the pattern of the conventional map (Figure 3).

In the Red-Yellow, Yellow and Red Latosols (Oxisols) classes, the distribution was most similar to the conventional map with the classification of R4444_TP12d and R4848_TP12d networks. In the networks R4343_TP13d and R5345_TP13d, there is a certain dominance of Red Latosols (Oxisols) compared to Red-Yellow Latosols (Oxisols). In addition, the Yellow Latosols (Oxisols) are practically suppressed in the R4343_TP13d network classification. Although, in all classifications, the networks allocated these soil occurrence areas correctly, there was an overestimation of Yellow Latosols (Oxisols) distribution and an excess in Red Latosols (Oxisols) distribution, especially in the R4343_TP13d classification. This occurred similarly for the Red and Yellow-Red Argisols (Ultisols) classification and distribution, with 
predominance of Yellow-Red Argisols (Ultisols). In the class with predominantly Yellow Argisols (Ultisols), all networks allocated this soil occurrence area and distribution correctly and consistently with the conventional map. The soil type had an irregular and dotted distribution at various landscape points with low representativeness per area.

In the domain of Red Argisols (Ultisols), the best classification occurred for [R4444_TP12d] and [R4848_TP12d] networks of set 12, while in the networks of set 13 , the classification result was slightly inferior. This was also the case with the Red Latosols (Oxisol) class, with superior performance for [R4848_TP12d], when compared to set 13 networks. Table 8 shows the classification performance for each predicted type, in the four selected networks (sets 12 and 13), with their respective overall accuracy values. Thus, it can be inferred that the variable curvature profile slightly obscures the result when used together with curvature plan, as in set 13. Chagas (2006) reported a low efficiency of curvature plan to differentiate some soil types, in spite of being important to separate others at concave curvature locations.

The classification matches and overall accuracy for Fluvic Neosols (Entisols) were high in all networks, with less than $6 \%$ of incorrectly allocated pixels, but its distribution on the terrain was the most irregular, compared to the conventional map, and appeared to be more scattered across the whole study area. Network R4848_TP12d distributed this soil type consistently with the conventional map. In all other classifications, there was excess in the distribution of areas belonging to this type, to a greater or lesser degree. Although the occurrence sites were correct, the network generalization process for Fluvic Neosols (Entisols) standard was inconsistent in the class distribution. This can be explained by the fact that small areas of intermontane alveoli occur throughout the study area, with smooth relief and very similar declivity values, inserted in rough, undulating and hilly relief areas. This information was already detected by the digital elevation model (DEM), reported by Dantas (2001). If the intermontane alveoli were eliminated from DEM, the results for this soil distribution would possibly be better.

The confusion degree in some classes of the resulting maps was due to the difficulty of establishing more accurate soil-landscape relations in the study area. According to the used pixel size and large geological heterogeneity in the area, diverse source materials can be produced, with occurrence of polychrome soils (bicolor) in a same profile. In addition, a high degree of pedological complexity in the area, with very similar landscape patterns, where some soil types occur and how they are distributed within landscape. Sometimes, they occupy the same position in landscape, making it difficult to separate them with $100 \%$ accuracy by the SiBCS characteristics (Embrapa, 2006), where some criteria are too subtle to establish a clear differentiation in the landscape.

McKenzie \& Austin (1993) emphasize the presence of geological structures such as dikes that can control the soil distribution pattern in a landscape. Dikes of basic material are frequent in the area, however, because of the generalization degree, the geological maps of Matos et al. (1980) and DRM (1982) fail to show their occurrence and spatial distribution. Another cause may be the unsuitability of the environmental variables in representing variations in soil characteristic, or even in their proper generation, where their accuracy is determined by the spatial resolution of the DEM, by which they were calculated (Thompson et al., 2001). In this study, a 30-m spatial resolution DEM was used, which is considered appropriate and compatible with scale of original topographic maps, and the interpolation method used for the construction is suitable for rough relief areas.

Of all combinations tested, the potential to predict soil types of the variables of sets 12 and 13 was best,

Table 8. Performance of ANN classifications of the sets 12 and 13

\begin{tabular}{|c|c|c|c|c|c|}
\hline \multirow{2}{*}{\multicolumn{2}{|c|}{ Output class }} & \multicolumn{4}{|c|}{ Overall accuracy within Neural Networks (Sets $12^{(1)}$ and 13 TP) } \\
\hline & & R4444_TP12d & R4848_TP12d & R4343_TP13d & R4545_TP13d \\
\hline 1 & RO & 97.2 & 98.0 & 96.0 & 96.8 \\
\hline 2 & CXbd & 100.0 & 98.8 & 96.0 & 100.0 \\
\hline 3 & LAd & 92.4 & 93.6 & 98.4 & 88.0 \\
\hline 4 & LAdh & 93.6 & 88.8 & 96.8 & 93.6 \\
\hline 5 & LVAd & 99.6 & 99.6 & 100.0 & 98.0 \\
\hline 6 & $\mathrm{LVd}$ & 76.8 & 90.4 & 88.8 & 85.6 \\
\hline 7 & PVAd & 98.0 & 98.0 & 98.0 & 98.0 \\
\hline 8 & PVd & 92.0 & 92.8 & 85.6 & 83.6 \\
\hline 9 & $\mathrm{RY}$ & 96.0 & 93.6 & 96.0 & 95.6 \\
\hline 10 & PAd & 100.0 & 100.0 & 100.0 & 100.0 \\
\hline
\end{tabular}

(1) Set 12 without the variable curvature profile. 
with a percentage of hits above $90 \%$ of training samples, high Kappa index and lower variance values (Tables 3 to 8). Although the results for the Kappa index were excellent for all four selected classifiers $(>0.90)$ when using sets of validation samples, as suggested by the reference values stipulated by Landis \& Koch (1977) and Monserud \& Leemans (1992), the predicted soil maps differed.

\section{CONCLUSIONS}

1. Using the same set of soil profiles as by the conventional approach, the concurrent use of terrain attributes, geological information and indices derived from Landsat 7 images allowed the establishment of soil-landscape relations as they occur in the study area, improving the discrimination among component members of the mapping units.

2. Results confirm the potential of using neural network approach, since the resulting maps were consistent with and similar to the conventional soil map, but show more spatial details.

3. As well as facilitating soil mapping in medium scale, this approach contributes to the development of digital soil mapping in Brazil, especially considering the availability of remote sensing data at zero cost, ease of obtaining terrain attributes and use of free software.

\section{ACKNOWLEDGEMENTS}

The authors want to thank the Foundation for Research Support of the State of Rio de Janeiro FAPERJ, for granting resources by the Program Jovem Cientista do Nosso Estado (E26/103 062/2012).

\section{LITERATURE CITED}

CALDERANO FILHO, B. Análise geoambiental de paisagens rurais montanhosas da Serra do Mar utilizando redes neurais artificiais. Subsídios a sustentabilidade ambiental de ecossistemas frágeis e fragmentados sob interferência antrópica. Rio de Janeiro, Universidade Federal do Rio de Janeiro, 2012. 332p. (Doctoral thesis)

CARVALHO JÚNIOR, W. Classificação supervisionada de pedopaisagens do domínio dos mares de Morros utilizando Redes Neurais Artificiais. Viçosa, MG, Universidade Federal de Viçosa, 2005. 143p. (Doctoral thesis)

CHAGAS, C.S. Mapeamento digital de solos por correlação ambiental e redes neurais em uma bacia hidrográfica no domínio de Mar de Morros. Viçosa, MG, Universidade Federal de Viçosa, 2006. 223p. (Doctoral thesis)

CONGALTON, R.G. \& GREEN, K. Assessing the accuracy of remotely sensed data: Principles and practices. New York, Lewis Publishers, 1999. 160p.
DANTAS, M.E. Geomorfologia do Estado do Rio de Janeiro. In: COMPANHIA DE PESQUISA DE RECURSOS MINERAIS - CPRM. Serviço Geológico do Brasil. Estudo Geoambiental do Estado do Rio de Janeiro. Rio de Janeiro, CPRM/Embrapa Solos; Niterói, DRM-RJ, 2001. CD-ROM

DEPARTAMENTO DE RECURSOS MINERAIS - DRM. Projeto Carta Geológica do Estado do Rio de Janeiro. Folhas: Duas Barras e Trajano de Morais, 1982.

EMPRESA BRASILEIRA DE PESQUISA AGROPECUÁRIA EMBRAPA. Centro Nacional de Pesquisa de Solos. Procedimentos normativos de levantamentos pedológicos. Brasília, 1995. 101p.

EMPRESA BRASILEIRA DE PESQUISA AGROPECUÁRIA EMBRAPA. Centro Nacional de Pesquisa de Solos. Sistema brasileiro de classificação de solos. 2.ed. Rio de Janeiro, 2006. 306p.

ENGEL, B. Estimating soil erosion using RUSLE (Revised Universal Soil Loss Equation) using ArcView. West Lafayette, Purdue University, 2003.

ENVIRONMENTAL SYSTEMS RESEARCH INSTITUTE ESRI. ArcGIS 9.2: Getting started with ArcGIS. Redlands, 2004. 272p.

FOODY, G.M. \& ARORA, M.K. An evaluation of some factors affecting the accuracy of classification by an artificial neural network. Inter. J. Rem. Sens.,18:799-810,1997.

FLORINSKY, I.V. The Dokuchaev hypothesis as a basis for predictive digital soil mapping (On the 125th Anniversary of Its Publication). Eur. J. Soil Sci., 45:445-451, 2012.

FU, P. \& RICH, P.M. The solar analyst 1.0: User manual. Vermont, Helios Environmental Modeling Institute, 2000. $49 \mathrm{p}$.

GRINAND, C.; ARROUAYS, D.; LAROCHE, B. \& MARTIN, M. Extrapolating regional soil landscapes from an existing soil map: Sampling intensity, validation procedures, and integration of spatial context. Geoderma, 143:180-190, 2008.

JAVANNS. Java Neural Network Simulator. Version 1.1. University of Tübingen, 2001. Available at: <http://wwwra.informatik.uni-tuebingen./software/JavaNNS/ welcome html>.

JENNY, H. Factors of soil formation; a system of quantitative pedology. New York, McGraw-Hill, 1941. 281p.

KEY, J.; MASLANIK, J.A. \& SCHWEIGER, A.J. Classification of merged AVHRR and SMMR artic data with neural networks. Photogr. Eng. Rem. Sens., 55:1331-1338, 1989.

LANDIS, J.R. \& KOCH, G.G. The measurement of observer agreement for categorical data. Biometrics, 33:159-174, 1977.

MATOS, G.; FERRARI, P. \& CAVALCANTI, J. Projeto Faixa Calcaria Cordeiro-Cantagalo. Belo Horizonte, DNPM/ CPRM, 1980.

McBRATNEY, A.B.; SANTOS, M.L.M. \& MINASNY, B. On digital soil mapping. Geoderma. 117:3-52, 2003. 
McKENZIE, N.J. \& AUSTIN, M.P. A quantitative Australian approach to medium and small scale surveys based on soil stratigraphy and environmental correlation. Geoderma, 57:329-335, 1993.

McKENZIE, N.J. \& RYAN, P.J. Spatial prediction of soil properties using environmental correlation. Geoderma, 89:67-94, 1999.

MENDES, J.C.; TEIXEIRA, P.A.D.; MATOS, G.C.; LUDKA, I.P.; MEDEIROS, F.F. \& ÁVILA, C.A. Geoquímica e geocronologia do granitoide Barra Alegre, faixa móvel Ribeira, Rio de Janeiro. R. Bras. Geoci., 37:101-113, 2007.

MINASNY, B.; HOPMANS, J.W.; HARTER, T.; ECHING, S.O.; TULI, A. \& DENTON, M.A. Neural networks prediction of soil hydraulic functions for alluvial soils using multistep outflow data. Soil Sci. Soc. Am. J., 68:417-430, 2004.

MONSERUD, R.A. \& LEEMANS, R. Comparing global vegetation maps with the Kappa statistic. Ecol. Modell., 62:275-293, 1992.

MOORE, I.D. Soil attribute prediction using terrain analysis. Soil Sci. Soc. Am. J., 57:443-452, 1993.

SARMENTO, E.C.; FLORES, C.A.; WEBER, E.; HASENACK, H. \& PÖTTER, R.O. Sistema de informação geográfica como apoio ao levantamento detalhado de solos do Vale dos Vinhedos. R. Bras. Ci. Solo, 32:2795-2803, 2008.
SIRTOLI, A.E. Mapeamento de solos com auxílio da geologia, atributos do terreno e índices espectrais integrados por redes neurais artificiais. Curitiba, Universidade Federal do Paraná, 2008. 96p. (Doctoral thesis)

THOMAS, A.L.; KING, D.; DAMBRINE, E. \& COUTURIER, A. Predicting soil classes with parameters derived from relief and geologic materials in a sandstone region of the Vosges mountains (Northeastern France). Geoderma, 90:291-305, 1999.

THOMPSON, J.A.; BELL, J.C. \& BUTLER, C.A. Digital elevation model resolution: Effects on terrain attribute calculation and quantitative soil-landscape modeling. Geoderma, 100:67-89, 2001.

VIEIRA, C.A.O. Accuracy of remotely sensing classification of agricultural crops: A comparative study. Nottingham, University of Nottingham, 2000. 352p. (Doctoral thesis)

ZHOU, B.; ZHANG, X.-G. \& WANG, R.-C. Automated soil resources mapping based on decision tree and Bayesian predictive modeling. J. Zhejiang. Univ. Sci., 5:782-795, 2004.

ZHU, A.X. Mapping soil landscape as spatial continua: the neural network approach. Water Resour. Res., 36:663677, 2000. 